\title{
THE HISTORY OF MOSQUE'S MINARET DESIGN IN LEMBAH KELANG, MALAYSIA
}

\author{
AIZAN ALI MAT ZIN \\ Department of Islamic History and Civilization, Academy of Islamic Studies, \\ Universiti Malaya, Kuala Lumpur, Malaysia
}

\begin{abstract}
This article explores the history of mosques' minaret design in Lembah Kelang. The aim is to categorize the minaret in Lembah Kelang and to document its typology. The lingering issue is fusion in designing minaret raised by experts who prefer to maintain the traditional designs and sustain the uniformity. One pertinent question in this research was: what are factors that contribute to the innovation. Samples of one hundred mosques in Lembah Kelang were observed and findings were recorded. Methods of data collection were twofold: documentation and observation. Collected data were analysed by deductive, inductive and comparative analyses. Findings exhibit that a minority of architects prefer to modernise the minaret according to the trend without neglecting the need and budget. On the other hand, the majority of architects sustain the traditional design answering the local community choice. It seems that accommodating needs and budget are two main factors in designing modern minaret of mosques in Lembah Kelang. In conclusion, fusion is inevitable.

Keywords: Islamic architecture, mosques, Islamic civilization, Islamic history, Malaysia.
\end{abstract}

\section{INTRODUCTION}

Minaret is a platform for calling Muslims to prayer in congregation at a mosque. It is distinguishable with its tall design and function as a symbol of the Muslim communities' unity. Al-Bayati [1], Khasawneh [2] claims that minaret's design developed from square, transformed into a polygon in the next level and then to the cylindrical main shaft. The top of minaret formed another storey and it was the crowned by a dome or conical roof. This design reflected in minarets of Lembah Kelang.

\section{METHODOLOGY}

This research is based on qualitative data and it generates quantitative data as reported in the later findings and discussions. Qualitative research is multi methods in focus, involving an interpretative and naturalistic approach to its subject matter. This means that qualitative researchers study things in their natural settings, attempting to make sense of, or interpret, phenomena in terms of the meanings people bring to them. Qualitative research involves the studied used and the collection of a variety of empirical materials [3]. Data collections are twofold as follows:

- Documentation: primary and secondary sources are referred throughout the study. Primary source such as records of registered mosques in Lembah Kelang and pictures taken by researcher during the observation sessions provides main data. Secondary sources such as previous research reports also used to intensify data collection.

- Observation: Random stratified sampling was used to select 100 mosques in Lembah Kelang as research samples. 100 samples of mosques were observed to investigate the existence of minarets and its' design. The selected mosques are located in districts of Ampang, Bangsar, Damansara, Subang Jaya, Shah Alam, Damansara, Petaling Jaya, Cheras, Kajang, Kuala Lumpur, Klang Gate, Gombak, 
Salak Selatan, Puchong, Jinjang and Kepong. Field research was done in one year, on part time basis. Pictures and details were recorded by using DSLR camera and video recording to simplify analysis process.

Pool of collected data was inductively, deductively and comparatively analyzed to engender the classification of minarets design. It originated the typology of minarets design in Lembah Kelang and exhibit findings as follows.

\section{FINDINGS AND DISCUSSION}

In Lembah Kelang, there are two types of mosques' designs: with minaret and without minaret. Why mosques' building need minaret? At the beginning of Islamic history, minaret used by muezzin i.e. prayer caller to enhance his voice and reach the residents from near and far. Nowadays, sound technology offer microphone and speaker to enhance the voice of muezzin. Hence the muezzin doesn't need to climb the peak of minaret but the speaker. However, minaret is still relevant since speaker need high-raised building as well to ensure clarity of the sound [4]-[6]. Mosques without minaret will use the highest edges of mosques' building and becomes disharmonized with the whole buildings. Follows are samples of mosque which use minaret to place the speaker.

The functions of minaret throughout the history of Islamic architecture are varies. Petersen [7] and Hillenbrand [8] argue that the purpose of minaret in Abbasid period served to demonstrate the power of Abbasid religious authority. Those opposed to Abbasid power would not adopt this symbol of conformity. Although later, minaret seems gradually become synonymous with Islamic architecture especially in mosques and palaces. In addition, Petersen said that minaret also functioned as a lighthouse such as The Great Mosque of Banten in North Java. On the other hand, Cragg [9] argues that the call of the minaret is an affirmation of unity and the non-entity of idols; an Islamic order for human society. This proclaims is in line with the usage of minaret by muezzin to call for prayer in Lembah Kelang.

Nasir [10], Halim [11], Azizul [12], [13] and Tajuddin [14] are of the opinion that local geography and climate factors in Malaysia have dictated the design of mosques in tropical areas must come with a roof and without minaret as protection for the building. Thus, the prayer hall has to come with a roof on top of its area.
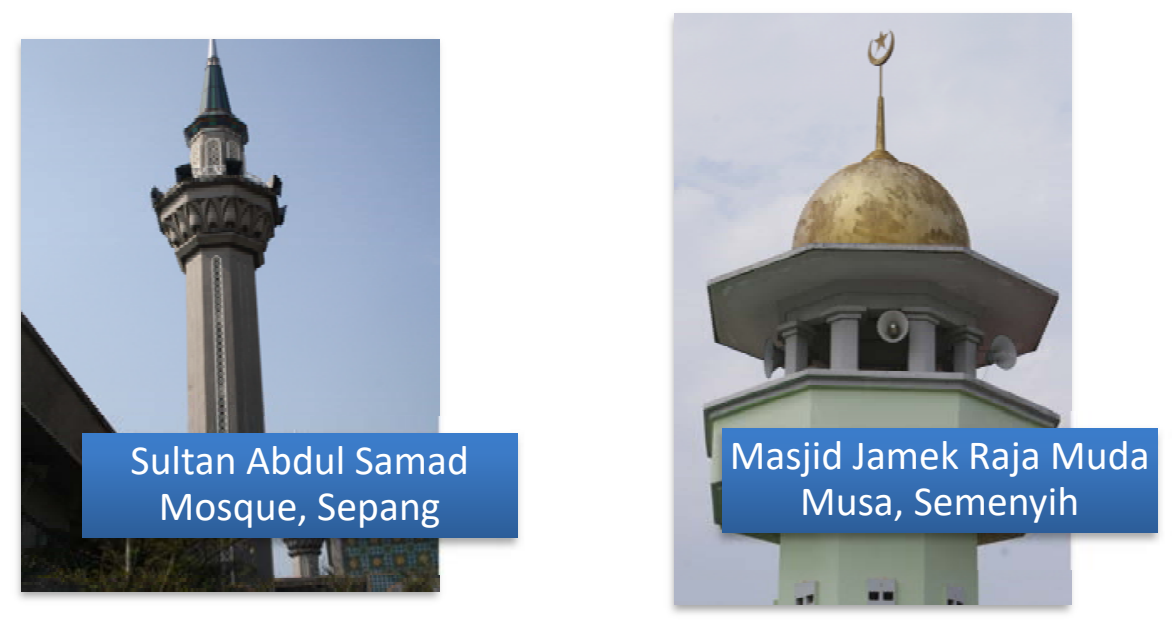

Figure 1: Speakers are located on minaret replacing muezzin in Lembang Kelang. 

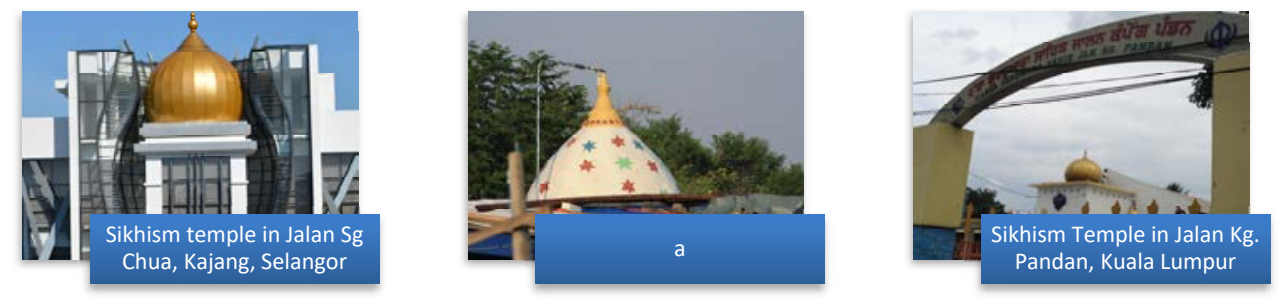

Figure 2: Dome of Sikhism and HinduismTemple in Lembah Kelang.

Compared to the mosques in the Arabia, the mosques in the Malay world have specific characteristics in the design of its roofs. Two or three-tiered pyramidal roofs are common in the traditional Malay mosques in the Peninsula. The roof design becomes a specific characteristic in the identification of traditional Malay mosques in the archipelago. Other than protecting the mosques from rain and heat, the two or three tiered pyramidal roofs has become a significant symbol to the identity of the Islamic communities in this region. The roof structure is supported by the structure of wooden main pillars. In contrast with their opinion of pyramidal roofs has become a significant symbol to the identity of Islamic community in this region, it was observed that 100 mosques in Lembah Kelang dominated by dome with and without minaret. On the other hand, domes also appear in other religion temples such as Hinduism and Sikhism in Lembah Kelang as shown in Fig. 2. It seems that a combination of dome and minaret is more significant symbol of Muslim in Lembah Kelang.

\subsection{Typology of minarets' design in Lembah Kelang}

The investigation was done in Lembah Kelang by using random stratified sampling in selection of 100 mosques as research samples. Observation on the selected samples exhibits the need of minaret to call for prayer is more manifest than latent symbol of mosques. Collected data from observation of 100 minarets were compared and categorized. Designs of mosque's minaret in Lembah Kelang were classified according to their geometrical shapes. They are cylinder, triangle, cone, square, rectangle, pentagon, hexagon, and octagon.

Lembah Kelang is an area in Malaysia, includes Kuala Lumpur (as a centre) and adjoining cities and town such as Ampang, Gombak, Selayang, Rawang, Petaling Jaya, Shah Alam, Subang Jaya, Klang, Puchong, Serdang, Kajang, Sepang, Putrajaya and Cyberjaya. Outcome of analysis are as follows.

Table 1 exhibit total number of every shape of minaret. However, the grand total is 103 out of 100 mosques. This is due to their combination shape. Seven minarets were built on square shape at the bottom followed by cylinder and cone at the middle and top of it. It appears that square shape is the most popular design. 

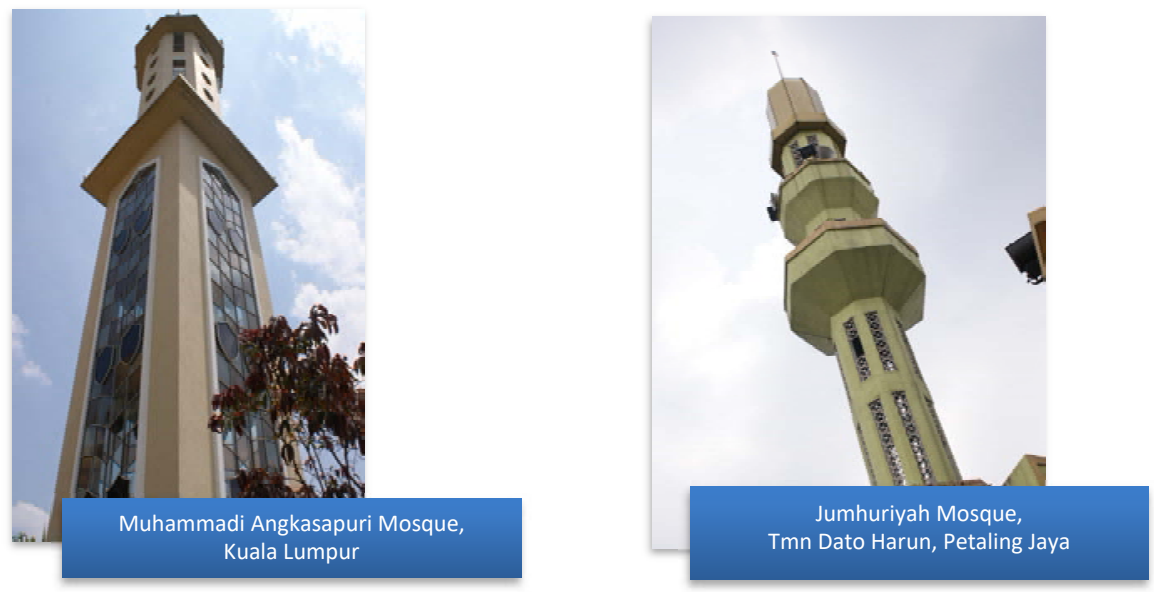

Figure 3: Samples of traditional minaret's design in Lembang Kelang.

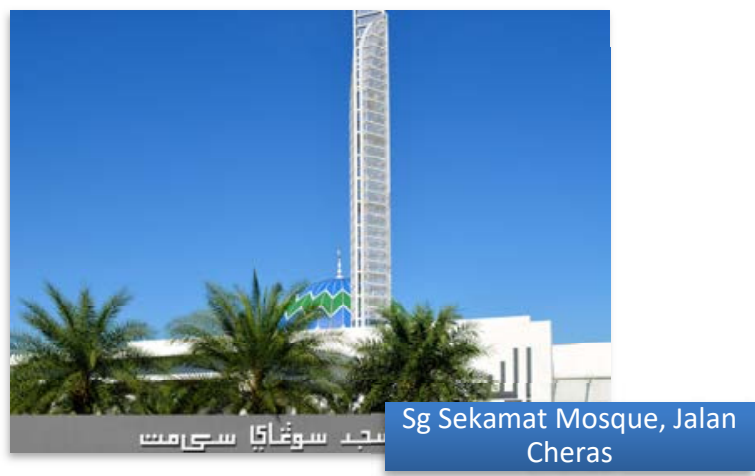

Figure 4: Sample of modern minaret's design in Lembang Kelang.

Table 1: Typology of minaret's design. (Source: samples from observation.)

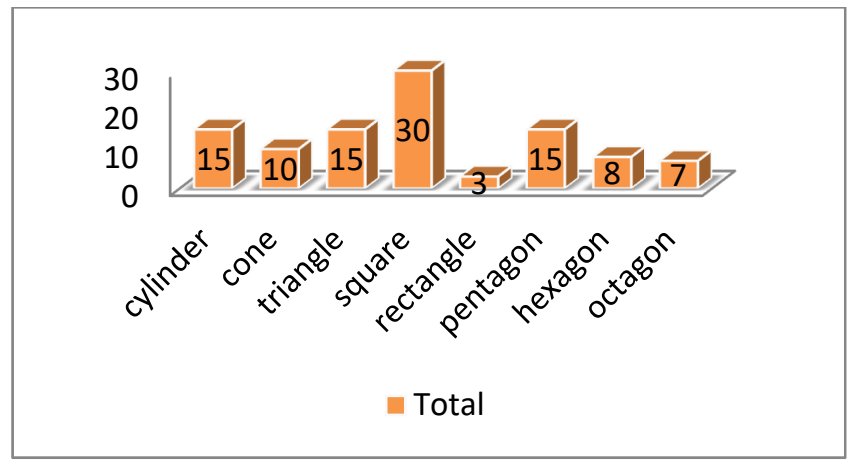




\section{CONCLUSION}

The existence of minaret in mosque buildings is of paramount importance. Dome and minaret seems to be symbol of the Muslim communities' presence in certain area of population. Once the notion is accepted, architect would design the minaret in harmony with the principle concept of the whole structure. It bears artistic works and becomes latent symbol of prayer place for Muslim in local community.

\section{ACKNOWLEDGEMENTS}

The author is indebted to the Universiti Malaya, Academy of Islamic Studies, Department of Islamic History and Civilization for granting a conference leave and paying for the conference fee. Secondly, my thanks go to Humanities and Ethics Research Cluster for a grant in 2012 on this area (RG276-11HNE). Last but not least, thanks to all contributors and correspondents who help me in gathering data throughout the study.

\section{REFERENCES}

[1] Al-Bayati, B., The City and The Mosque. AARP, Oxford, p. 63, 1984.

[2] Khasawneh, Environmental Aspects of Islamic Architecture, Mphil, Lampeter, p. 26, 2005.

[3] Groat, L. \& Wang, D., Architectural Research Methods. John Wiley \& Sons, USA, Passim, 2002.

[4] Dimon, M.N. et al., Subjective Disturbance Perception of Various Ambience Noise Levels of a Mosque: A Mathematical Modelling Analysis. Amsterdam: The 96th Audio Engineering Society Convention. 26th Feb.-1st Mar. 1994. Passim.

[5] Said, A.K. et al., Acoustics and Sound System Design in Domed Public Buildings: A Computer Modelling Analysis. Melbourne: 4th Australian Regional Convention World Congress Centre, 24th-26th Aug. 1993. Passim.

[6] Mahmod, N., Sound Level Meter-1. Tesis B.E.E, UTM Skudai. Passim, 2008.

[7] Petersen, A., Dictionary of Islamic Architecture. London: Routledge, pp. 187-190, 1996.

[8] Hillenbrand, R., Islamic Art and Architecture. London: Thames \& Hudson, p. 46, 2002.

[9] Cragg, K., The Call of The Minaret, New York, Oxford University Press, Passim, 1956.

[10] Nasir, A.H., Ciri-ciri Islam dalam Seni Bina Tradisi Melayu-Pencapaian dan cabaran”. Balai Seni Lukis Negara, 14-15 Oct. 1992.

[11] Halim, N.A., "Masjid Melayu dan Sentuhan Islam" dlm. Dewan Budaya, Jil. 15 hlm.23-25 Jan. 1993.

[12] Azizul, A.A., Masjid Budaya dan Seni Bina. Shah Alam Unit Penerbitan Universiti. UPENA, 2010.

[13] Azizul, A.A., Perbahasan Ciri-Ciri Seni Bina Islam. Utusan Malaysia, 8 Mar. 2005.

[14] Tajuddin, M.R., Mohd, Mosque as a community Development Centre. Johor Bahru: Penerbit Universiti Teknologi Malaysia, 1998. 